\title{
In memoriam: Jean-Alex Michard
}

\author{
Robert Alberny $^{1,2, *}$, Gérard Bernard ${ }^{1,2,3}$, Jean-Pierre Birat ${ }^{1,2}$, Pierre Gugliermina ${ }^{3}$, Rémi Nicolle ${ }^{1,2}$, and \\ Jean-Marc Steiler ${ }^{1,2}$ \\ ${ }^{1}$ Irsid, Maizières-lès-Metz, France \\ ${ }^{2}$ Irsid, St Germain-en-Laye, France \\ ${ }^{3}$ Solmer, Arcelor, Fos-sur-Mer
}

Received: 17 September 2018 / Accepted: 20 September 2018

\section{Jean-Alex Michard}

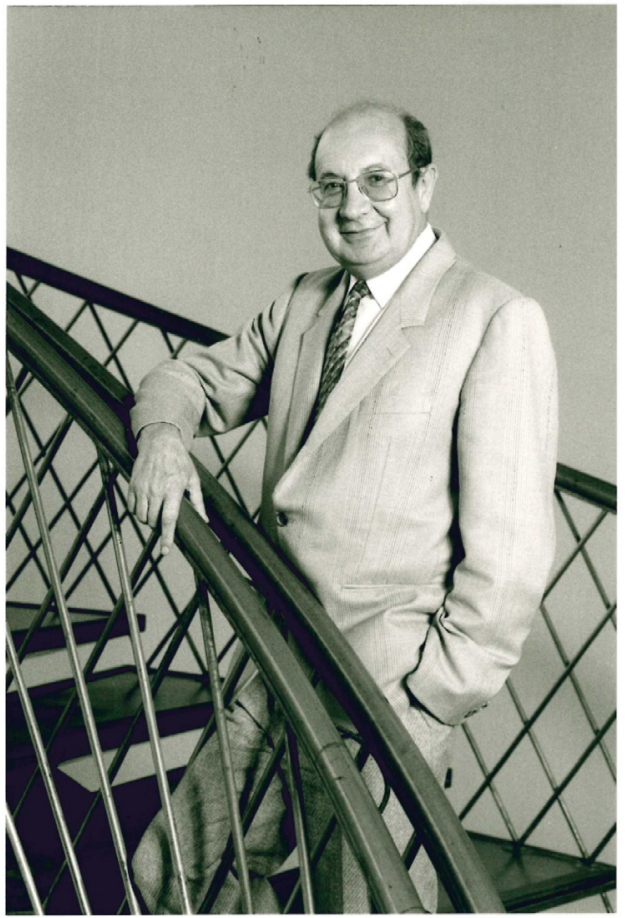

Cliché S. Vernédal - ArcelorMittal Research

Jean-Alex Michard passed away on Thursday, May 15, 2018. All those who were close to him in the steel industry and in industrial research can testify of his empathy towards people in general and each one of them in particular. This is why the present obituary tells a series of

\footnotetext{
* e-mail: alberny.robert@orange.fr
}

stories, where the signatories recollect how challenging and intellectually pleasing it was to interact with him, not as a boss but as a co-worker, a co-discoverer! As if they were alone in a bubble with him!

His professional life started at the Saulnes research station, where he was hired in 1952 by Lucien Coche, in IRSID's Minerais-Coke-Fonte (ironmaking) department. In a "joyful team", as he himself called it, he was in charge of the studies on ores and he launched foresight studies on the future of the Lorraine iron ore field [1-3]. His enthusiasm for research and industrial life strongly directed at the future, as well as his desire to convince, appeared from the very beginning of his professional life.

\section{Pioneer in the field of ironmaking}

Jean-Alex Michard will remain first of all a pioneer in the field of the blast furnace, as the engineer-scientist who, along with André Rist, brought about the first physicochemical model of how this reactor functions, a major contribution to the world scientific community; his approach, published at the end of the 1950s, was based on the results of vertical probes. Following the contributions of Kitaev and Reichardt, the predictive model of the operating point of the blast furnace that he developed was a fundamental breakthrough compared to the statistical descriptions of the time. It opened the door to the automation of the blast furnace [4-6].

He thus contributed to the creation of a French blast furnace school of international fame [7].

J.A. Michard was a man of strong opinions. For example, he was a powerful advocate of the development of the sintering of iron ores, which he considered as an absolute prerequisite for the smooth operation of the blast furnace and the further reduction of coke consumption. Indeed coke consumption dropped regularly from the 1960s to the 1980s [8-10]. In his mind, sintering was an integral part of the image he had built of the blast furnace. 


\section{Continuous Casting, the next technological revolution in the steelmill}

Jean-Alex Michard took upon himself to maintain a lively continuous discussion on the evolution of process technology in the iron and steel industry.

In the field of Continuous Casting (CC), which was still an emerging technology with a small market share in 1970 , he had already asked IRSID to compare the benefits of the new technology with those of ingot casting and slabbing in the case of the SOLMER Fos-sur-Mer steelmill project, on which he was working. This was new for IRSID researchers, who had been focused purely on technical issues until then, as they had to take on economic issues. The construction of a slabbing mill at Fos was by then almost decided and it was impossible for Michard to convince the management at the time of the merits of the calculations that demonstrated the benefits of running a steel mill relying only on Continuous Casting. Indeed, the management of SOLLAC, the parent company of SOLMER, had become convinced that it was impossible for Continuous Casting to compete with ingot casting in the case of rimming steel, based on the metallurgical examination of Continuous Casting slabs originating from $\mathrm{CC}$ production.

Continuous Casting had another major drawback, according to its detractors at the time, because it did not generate enough scrap-this is indeed one of its major advantages, a much high metallic yield! This was bad news for the BOF process, which needed enough scrap to ensure its heat balance, and thus a "clear and obvious" disadvantage of CC: external, high quality and expensive scrap would have to be bought on the market, which would overturn any economic advantage that Continuous Casting might have shown. Tongue-in-cheek, Michard killed this sophism by suggesting that $10 \%$ of CC production should be reverted back to the converter as internal scrap, which would not deteriorate the economic balance of the process he added. This was an example of the wide range of rhetorical techniques that he used to push his ideas.

Eventually, when Usinor acquired a stake in SOLMER equal to SOLLAC's [11], SOLMER management decided to build one CC. As a matter of fact, Dunkirk \#2 steelshop had demonstrated that $100 \%$ CC was indeed feasible and profitable.

In 1976, Jean-Alex Michard asked IRSID to carry out heat transfer studies based on temperature measurements on the Continuous Casting mold in Fos, as it had been done in Dunkirk. With his ability to anticipate the future, he had already foreseen that these measurements could be used to detect the risk of breakouts: it took 15 years, though, for this technology to be applied in a steel mill exactly in this manner!

Jean-Alex Michard intervened in many other fields that were not his first technical specialty, for example in steelmaking.

\section{Jean-Alex Michard in Fos-sur-Mer}

At the beginning of the 1970s, Jean-Alex Michard left IRSID for the SOLMER steelmill in Fos, which was in the completion stage under the direction of P. Durand Rival.
He arrived with an indisputable aura in the field of blast furnaces due to the considerable progress he had made in understanding how these reactors worked. Moreover, he had also participated in the definition and design of the upstream part at the Fos mill, which was a reference in this area.

When he entered SOLMER in an operational position, the plant managers and himself quickly realized that he was not so much interested in direct management. The common sense that he showed in dealing with various problems still appealed to the general manager, P. Durand Rival, who took him as a personal technical advisor.

The career of Jean-Alex Michard from then on changed tack. His next big task was the implementation of Continuous Casting, as it was explained in the previous section.

At the end of the 1970s, the Fos-sur-Mer plant was in a rather difficult position, even though the facilities were brand new. The future of the site was in doubt and this called for a vigorous reaction. Three major actions were launched and brought back this Mediterranean steel plant to the top best in the world: an in-depth change in managerial style, the empowerment of all staff with technical progress total quality and a fast and significant improvement of process control. It is in this last sector that Jean-Alex Michard played an essential and structuring role. The "process sections" were reinforced and given clear support from the top management. Jean-Alex Michard guided the teams and their studies personally, he had the highest ambitions for them, i.e. to compete with the best steelmills in the world, which had been identified by benchmarking. This was the driving force for improving process operation in both the hot and cold plants.

In the late 1970s and the early 1980s, Jean-Alex Michard gave unwavering support to the transition from static models to dynamic models in operating the steelmaking converters. Curious and enthusiastic, and, moreover, frequently cooperating as a member of the team, he contributed to the gas carbometry development in order to guide the blow, which allowed forecasting the "end of blow", which was soon amplified by adding a sublance. Throughout this period, he was both a visionary, an advocate for the need to invest in equipment and human resources and to foster the link with the research teams at IRSID, he was a guide and a support for all the technical people in the steelmill. His search for excellence was decisive.

\section{Back to research at IRSID}

He was ecstatic when he was appointed Director General of IRSID in 1982. In this position, he was able to develop his abilities as a facilitator and also as a manager. He then expanded his responsibility by taking over the General Directorate of Research at Usinor-Sacilor, called to this position by President Francis Mer, who trusted him completely.

\section{The Japan team}

In 1969, the new director of IRSID, Lucien Coche, aware of the global leadership role of the Japanese steel industry, established close and permanent relations with ISIJ (Iron 
and Steel Institute of Japan) and hired the first members of the Japan's IRSID Team in charge of editing a newsletter summarizing the major facts from the Japanese technical and economic press, translating selected papers from Japanese journals and serving as translator at bilateral meetings. Jean-Alex Michard strongly developed this initiative and focused mainly on cooperation with Nippon Steel Corp.

\section{Michard and Japan}

The 1970s were the years when the economy in Europe toggled over from the 30 Glorious-Golden Years driven by the post-war reconstruction of the economy to a period of more modest growth... but did not quite understood what was happening until after it happened. The steel industry was being rebuilt around new plants in Dunkirk, Fos and eventually in Lorraine. The model for the steel industry, at that time, was in the US. On the other side of the world, however, Japan was also rebuilding its steel sector, but with a clear bias for innovation, in process technology, steel metallurgy and management style: the country had abandoned the copy-paste model that was their reputation and had decided to build brand new steel mills based on sintering strands, large blast furnaces, BOFs, continuous casters, powerful hot strip mills and more: innovation was the root of the new steelmill designs and the management style relied heavily on the skills of the work force, expressed in "quality circles" - a mixture of approaches, technological and social, which today is called social innovation.

Michard understood this before anyone else did: the technology park where one could observe the new steel production technology in the making was on the other side of Asia not across the Atlantic anymore.

Michard literally fell in love with Japan and its exciting and creative new steelmills. His preference went to the steelmill of Oita, erected in 1969 and which had chosen to base its production solely on Continuous Casting, the first steel mill in the world to make this choice historically. Michard, which had launched in France a broad Forum of discussion on new process technology on which to build real mills, "les nouvelles filières" (the new steel production routes), wrote a kind of fairy tale story, actually a uchronia, about Oita, "the metamorphoses of Oita" [12], where he proposed a brilliant and kaleidoscopic view of all possible steelmills, based on a series of transformation of the Oita steelmill, as it was at the time.

Incidentally, the Nouvelles Filières seminar had the political objective of changing the mind of IRSID's members regarding the development of new processes. Indeed, a new process, Strip Casting, had reached the point where a pilot was needed to progress further to what would be called TRL5 today, and the decision was being delayed because of the recollection of the Continuous Steelmaking process, which was remembered as a failure. Nobody spoke about Strip Casting explicitly during the seminar, but eventually a green light was given and a small pilot was built in Maizières, to be followed by the full-size, TRL7 demonstrator of Myosotis in Isbergues. This is another example of how Michard managed to convince... and get his way!
He made regular trips to Japan and encouraged his French colleagues also to travel to Tokyo. His trips to Japan numbered several per year and, overall, he probably outbid Jacques Chirac in this respect! The research people of IRSID were also nudged into exchanging with their Japanese counterparts and Michard organized annual technical meetings, centered on IRSID on the French side and Nippon Steel on the Japanese side-while, on the Germany-Japan axis, the connection was between VdEH and JISF, the steel federations, a clear difference in style.

Since then, Arcelor and ArcelorMittal have established an Alliance with Nippon Steel, which is the continuation, at a more organized business level, of the initial IRSID-NSC seminars.

\section{Scrap, the new raw material of the steel industry}

Late in his tenure as Research czar of Usinor-Sacilor, Michard understood that time had shifted once more and that making steel was moving towards a Circular Economy even before the words were invented and became popular. He found his inspiration in reading Japanese documents, which he translated with Yoko Sim and in which some of the first historical work on Material Flow Analysis (MFA) had been carried out-again before the concept and name of that field had been fully conceptualized.

The outcome was the understanding that scrap was not only a coolant for the BOF or a raw material for making special steels but was indeed a raw material of the same standing and importance as iron ore, which it should overcome, in terms of volume, in some distant future. He was back to basic, raw materials, which were ubiquitous, especially in Lorraine. IRSID launched a program on "the Cycle of Iron", which continues today at ArcelorMittal Research, in terms of research on scrap, and at IRT-M2P, on MFA. A large steelmill based on scrap and the Electric Arc Furnace technology was erected in Gandrange.

\section{Michard and the new steel frontiers}

Jean-Alex Michard was deeply convinced that the process technologies of the steel sector had to evolve continuously and that it was the role of Research to be in the lead to explore these deep changes. When at IRSID, he launched a program called "The new steel frontiers", which aimed at imagining a process route anchored in more and more continuous processes, themselves connected continuously without any intermediary buffers. Products had to be monitored and tracked along the process route in terms of product quality and process information: communication with upstream and downstream plants was paramount, with the objective of optimizing the whole route in a holistic way.

Michard's visionary thinking led him to revisit the role of the blast furnace $(\mathrm{BF})$ in the process route. Convinced that the BF had reached an evolutionary dead end by getting too close to perfection, which put it in a weak position, if conditions were to change. Therefore, he 
looked for ways to extend the limits of BF ironmaking in terms of productivity: under his impulsion, IRSID's researchers explored a paradigm shift in $\mathrm{BF}$ operation, in which ore would be added at the tuyere of the BF with the necessary energy input, the PTM process (PlasmaTuyere-Ore/Minerai), which would generate more hot metal with the same infrastructure above and below the tuyere level, especially the same BF hearth. The extra energy needed to reduce ore or prereduced iron, injected at the tuyeres, was delivered by plasma torches, therefore by electricity and not extra coke. This was to introduce a production flexibility of 15 to $25 \%$.

\section{Dispatched researchers and ambassadors from IRSID in the large steelmills}

As soon as he joined IRSID for the second time, Michard had become keenly aware of the difficulties of applying IRSID's work in the steelmills and he set about to correct the gap. He generalized the system of dispatched researchers, which he had experimented in SOLMER and whereby a research would accompany his work in the steel mill where it was to be implemented as an industrial application: the researcher thus went beyond his technical role to sell his work to the mill, adjust the conditions of implementation and help to empower his colleagues on site with the new technology.

He also invented the role of a Research Ambassador to a steel mill, which he called "Délégué Permanent Usine" or DPU. A head of department would be dispatched for one year and work closely with the technical direction of the steelmill, to act as a go-between at the interface of research and production: he could understand the local difficulties of implementing new technology and explain the new ideas being explored in the lab to the plant operators. Most large steelmills in France were eventually home to Research Ambassadors.

\section{Conclusion}

With his sense of humor, with his charisma, his ability to argue and to lead teams, his love for conviviality and dry white wine from Loire or Burgundy, his empathy towards everyone and especially curious, young and eager researchers, Jean-Alex Michard will be remembered as an example of a successful career in the service of research and industry. His colleagues and friends, the alumni of IRSID and ArcelorMittal Research, offer his brothers, his sons and all his relatives, their condolences and homage for all that Jean-Alex Michard has left them.

\section{References}

1. J.A. Michard, F. Paschal, Valeur du point de fer en fonction de la richesse du minerai, Ann. Mines 9, 67-86 (1967)

2. J. Michard, Upgrading Lorraine minerals enrichment by physical means, Rev. Ind. Miner. 48(7), (1966)

3. J.A. Michard, M. Boucraut, Recent trends in sintering of low grade self-fluxing Lorraine iron ore, Coke Oven and Raw materials Conference Proceedings AIME, 1962

4. F. Himber, J.A. Michard, Le haut-fourneau, un exemple de réacteur chimique à lit consommable, Chim. Ind. 95(5-6); 96 (7) (1966)

5. J. Michard, Étude du haut-fourneau, Cahiers du CESSID II, 1959

6. C. Staib, J. Michard, Control and automation of the blast furnace, Ironmaking tomorrow, Iron and Steel Institute, London, England, 1967, pp. 84-95

7. R. Nicolle, Blast furnace theory: the contribution of the French School, Rev. Met. Paris 102(3), 199-217 (2005)

8. J.A. Michard, A. Matraski, Contribution à la définition des propriétés physiques des agglomérés, Proceedings Second Symposium on Iron Ore Sintering, Paris, 1957

9. J.A. Michard, P. Dancoisne, G. Chanty, Blast furnace practice with $100 \%$ low grade self-fluxing sinter, Preprint Blast furnace, Coke oven and Raw materials Conference, Philadelphia, April 19-12, 1961

10. J. Michard, La marche du haut-fourneau lorrain à $100 \%$ d'aggloméré, Rev. Métall. 68(7-8), 497-516 (1971)

11. O. Bisanti, L'aventure sidérurgique de Fos-sur-Mer, Conférence prononcée à la CCI de Marseille et de Grenoble, Revue «Soleils d'acier» 15 avril 2002

12. J.A. Michard, Les métamorphoses d'Oita, Séminaire sur les nouvelles filières produits plats, Paris, 1985 